\title{
Review-Article
}

Buğra Berkan Bingöl, Ahmet Doğan Ataman, Mehtap Pekesen* and

Elif Vatanoğlu-Lutz

\section{Medicine in philately: History of Quarantine}

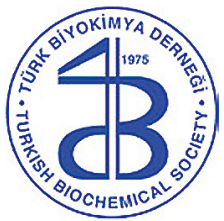

\section{Pullarda tıp: Karantina Tarihi}

https://doi.org/10.1515/tjb-2021-0035

Received February 17, 2021; accepted May 15, 2021;

published online June 18, 2021

\section{Abstract}

Objectives: This article provides an overview through philately on the history of the quarantine ap-plications which dominate the whole world nowadays because of the COVID-19 pandemic.

Content: In this review article, the History of Quarantine is enriched with philatelic examples and tried to explain.

Summary: Quarantine is defined as the isolation of animals, people, or land to prevent the spread of diseases or pests. It is different from medical isolation, which is for people who have been infected with the disease. The word "quarantine" comes from quarantine, Italian language meaning "40 days". This is because of the 40-day isolation of ships and people practiced as a measure of disease prevention related to the plague. This practice was named "Quaranta" in the Republic of Venice, whose economy is based on trade, by keeping the ships coming to the city in the sea for 40 days off the city, so that the capital Venice will not be infected with epidemics.

Outlook: People's efforts to take precautions against a possible pandemic risk are a practice that has been going

\footnotetext{
*Corresponding author: Mehtap Pekesen, Akdeniz University, Vocational School of Health Services, Department of Health Care Services, Antalya, Turkey, E-mail: mehtappekesen@gmail.com. https://orcid.org/0000-0003-2193-1675

Buğra Berkan Bingöl, Yeditepe University Medical Faculty, Istanbul, Turkey, E-mail: bberkanbingol@gmail.com. https://orcid.org/00000002-9361-2465

Ahmet Doğan Ataman, Medical Philatelist and Collector of Medical Stamps, Istanbul, Turkey, E-mail: drataman@hotmail.com. https:// orcid.org/0000-0003-3416-8648

Elif Vatanoğlu-Lutz, Yeditepe University Medical Faculty History of Medicine and Ethics, Istanbul, Turkey,

E-mail: drvatanoglu@yahoo.com. https://orcid.org/0000-00033156-4733
}

on for ages. Quarantine, which is among the measures to prevent the spread of infectious diseases, includes measures taken by avoiding contact with humans and animals in suspected cases exposed to infectious diseases for a period equal to the longest incubation period of the disease.

Keywords: history; infectious diseases; pandemics; philately; quarantine.

\section{Öz}

Amaç: Bu makale, filateli yoluyla COVID-19 pandemisi ile birlikte tüm dünyayı etkisi altına alan karantina uygulamalarının tarihi sürecine genel bir bakış sunmayı hedeflemektedir.

İçerik: $\mathrm{Bu}$ derleme yazısında Karantina Tarihi filatelik örnekler ile zenginleştirilerek anlatılmaya çalışılmıştır.

Özet: Karantina hastalıkların veya zararlıların yayılmasını önlemek için hayvanların, insanların veya bir arazinin izole edilmesi olarak tanımlanmaktadır. Hastalıkla enfekte olmuş insanlar için olan tıbbi izolasyondan farklıdır. "Karantina" kelimesi, İtalyanca "kırk gün” anlamına gelen karantinadan gelmektedir. Bunun nedeni, veba ile ilgili hastalıkları önlemenin bir ölçüsü olarak uygulanan gemilerin ve insanların 40 günlük tecrit edilmesidir. Bu uygulama ekonomisi ticarete dayanan Venedik Cumhuriyetinde, başkent Venedik'e salgın hastalık bulaşmasın diye kente gelen gemilerin 40 gün şehir açıklarında denizde bekletilmesi ile "Quaranta” adını almiştır.

Görünüm: İnsanların muhtemel bir salgın riskine karşı önlem alma çabaları ve karantina uygulamaları çağlar boyu devam etmiş bir uygulama olarak karşımıza çıkmaktadır. Bulaşıcı hastalıkların yayılmasını önlemeye yönelik önlemler arasında yer alan karantina, hastalığın en uzun kuluçka dönemine eşit bir süre boyunca bulaşıcı hastalığa maruz kalan şüpheli vakalarda insan ve hayvanlar ile temastan kaçınarak alınan tedbirleri içermektedir.

Anahtar kelimeler: Karantina; filateli; tarih; infeksiyon hastalıkları; salgınlar. 


\section{Introduction}

The word "Quarantine" is adopted from Italian origin "Quaranta" meaning 40. It indicates an obligatory separation of persons, and even sometimes animals and goods, from the majority as they might be exposed to a threat such as a contagious agent. In history, during the hard times of epidemics, quarantine measures have also been used against disadvantaged or marginalized groups or even for suppressing political riots. It was first introduced as an entry-ban for 30 days to ships and 40 days for land travelers. Since first introduced in 1377 in Dubrovnik [1] the term itself and the measures have changed, including isolation, security, and sanitary cordons (by armed guards), bills of health issued to ship and crews, fumigation and disinfection processes, but it still is in use as an essential element during the times of epidemic where the countries and local authorities need to take actions through a coordinated disease-control strategy (Figures 1, 2 and 3).

\section{Quarantine during plaque pandemic}

It was first introduced in port city Dubrovnik, on the Dalmatian coast, in 1377 but actually, the first-ever institutional organized sanitary measures were taken during the plague epidemic in 1347-1352 in Sicily [2]. Crews of the ship, rats, and contaminated goods arriving at the ports from the eastern Mediterranean to Sicily were thought to be the reason of spread not only in the city but also in Florance, Venice, Genoa [3] and then from the ports of Italy to

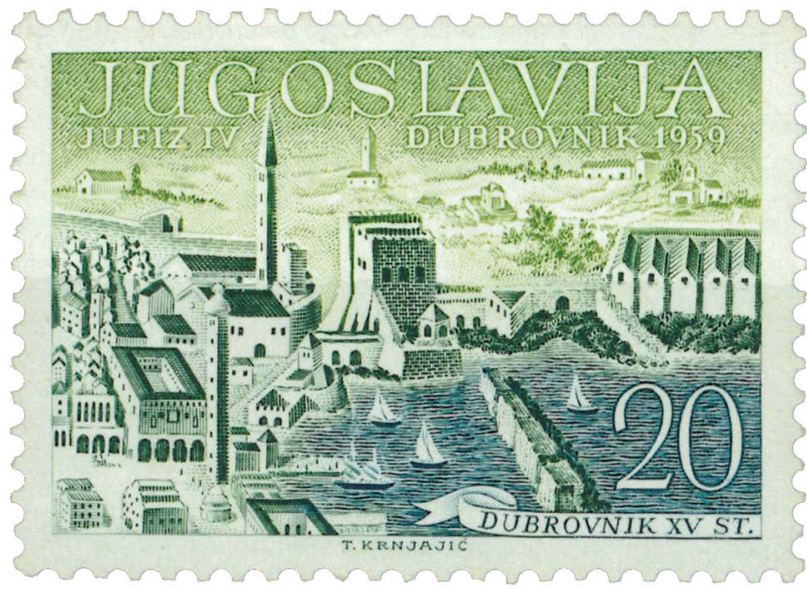

Figure 1: Yugoslavia 1959 Mi. 881.

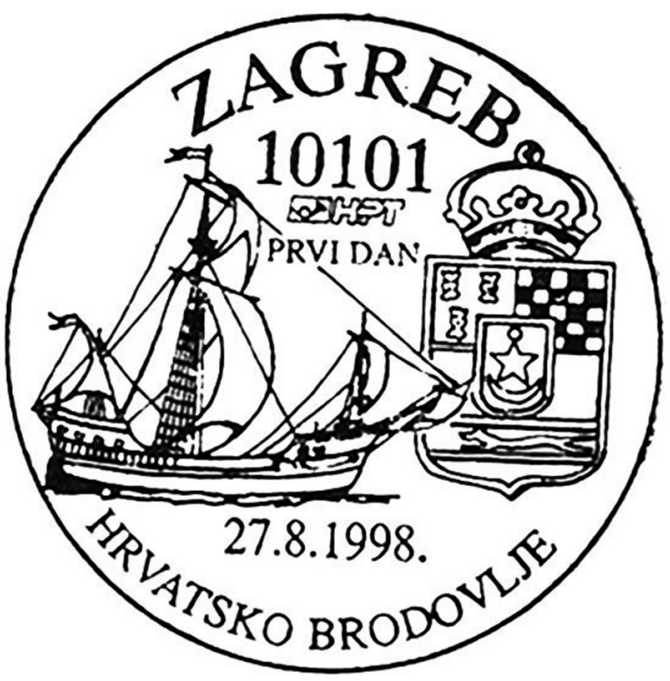

Figure 2: Cancellation from 1998.

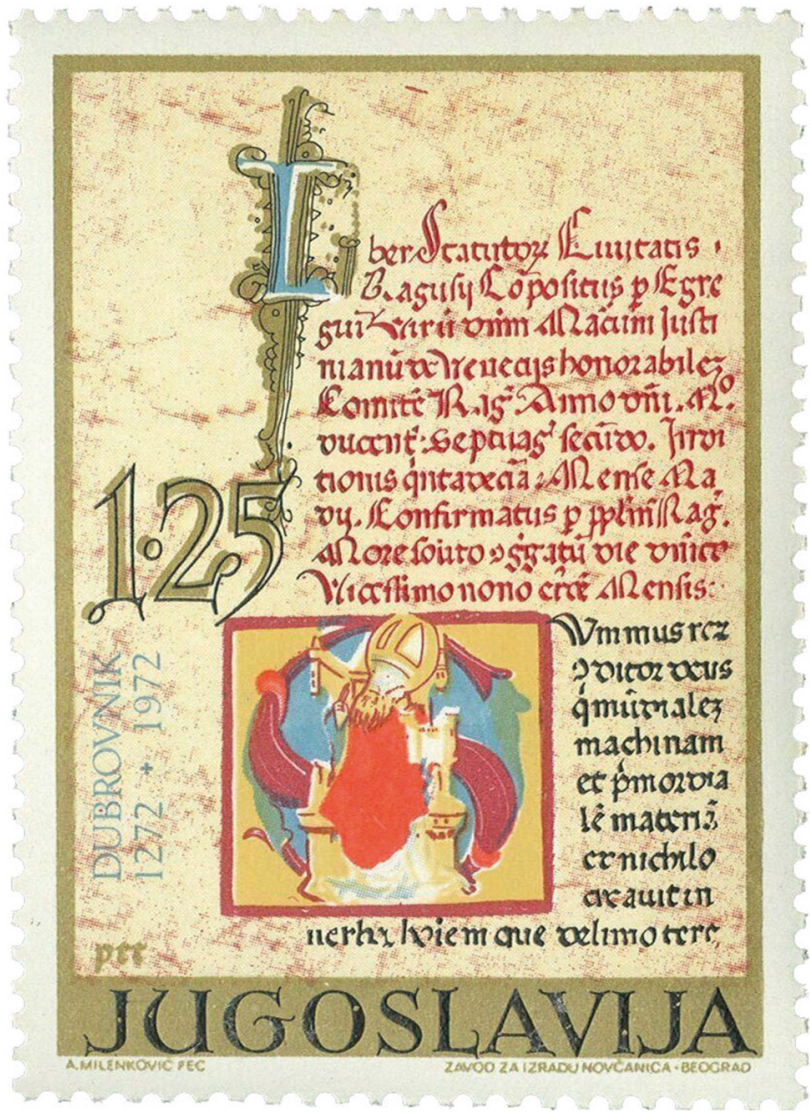

Figure 3: Yugoslavia $1972 \mathrm{Mi} .1449$ (First page of the statute of the Republic Ragusa).

other lands like France, Spain [4] and through the Alps Austria and central Europe.

Medicine was unable to find a cure but the only way for protection has seemed to prevent strangers from entering 
the cities. These strangers were especially merchants [5] but minority groups like Jews and persons with leprosy were also denied entry. The separation of healthy and infected persons was established by forming security cordons by armed police (Figures 4 and 5).

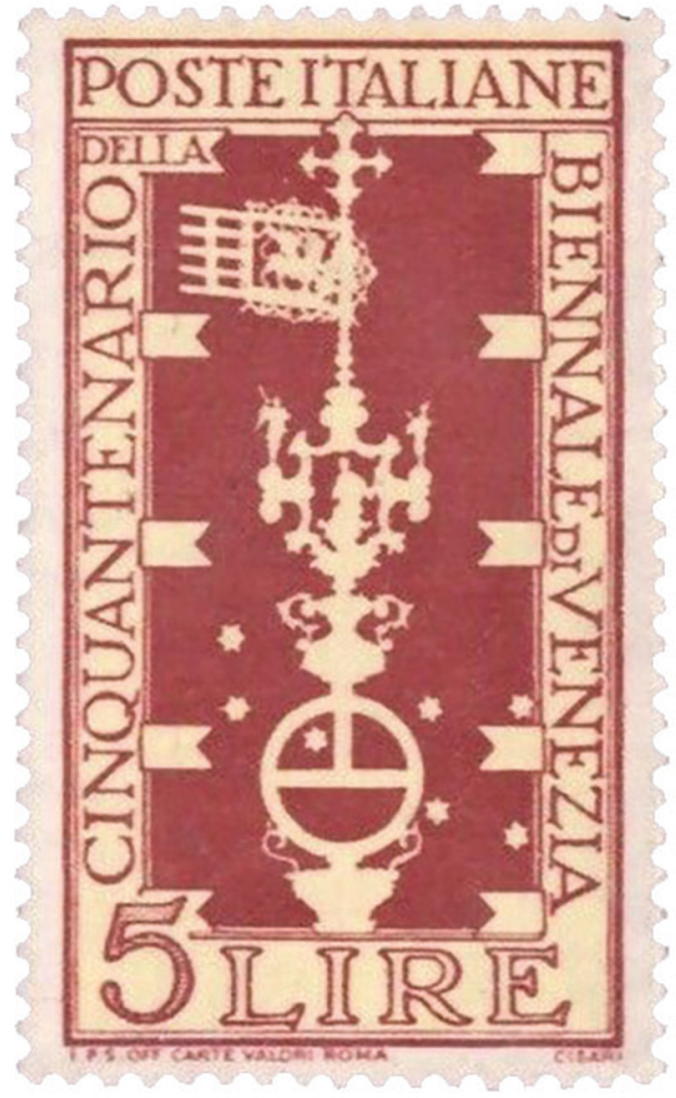

Figure 4: Italy $1949 \mathrm{Mi} .767$ (Lance, the flag of Venice and Ursa Major).

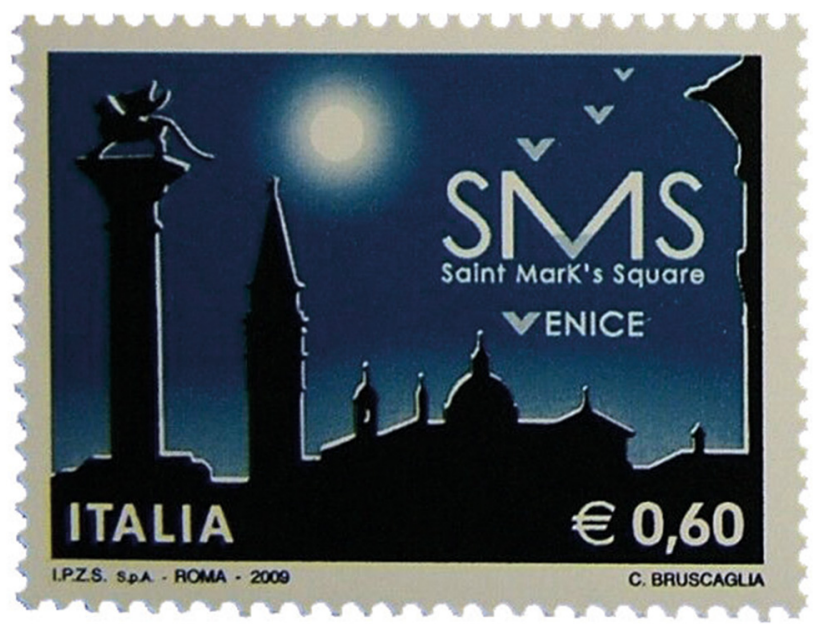

Figure 5: Italy 2009 Mi. 3309 (Saint Mark’s Square).
The first permanent plague hospital was opened on a small island called Santa Maria di Nazareth, by the Republic of Venice in 1423 and it was then called Lazaretto [6]. Other cities like Genoa and Marseille also adopted this system and formed permanent institutions in 1467 and 1476 respectively. These lazarettos were useful because they were both close to the cities for transferring the patients and also were far enough from the city centers to prevent the spread to healthy populations. Natural formations like rivers were thought to be advantageous while locating lazarettos in order to form barriers but where inapplicable moats were also in use. Other than the isolation of exposed crew members of the ship, these centers were also used as disinfection centers for the goods these ships carry. They were held in rooms with continuous ventilation and even wax and sponge were immersed in running water for $48 \mathrm{~h}$ [7] (Figure 6).

In the years followed, Hippocrates' theories regarding acute illnesses to reveal in 40 days were proven but the systems of precaution were also evolved. By the improvement in trading, the next step to reduce the spread was seen to establish bills of health that indicate the sanitary status of

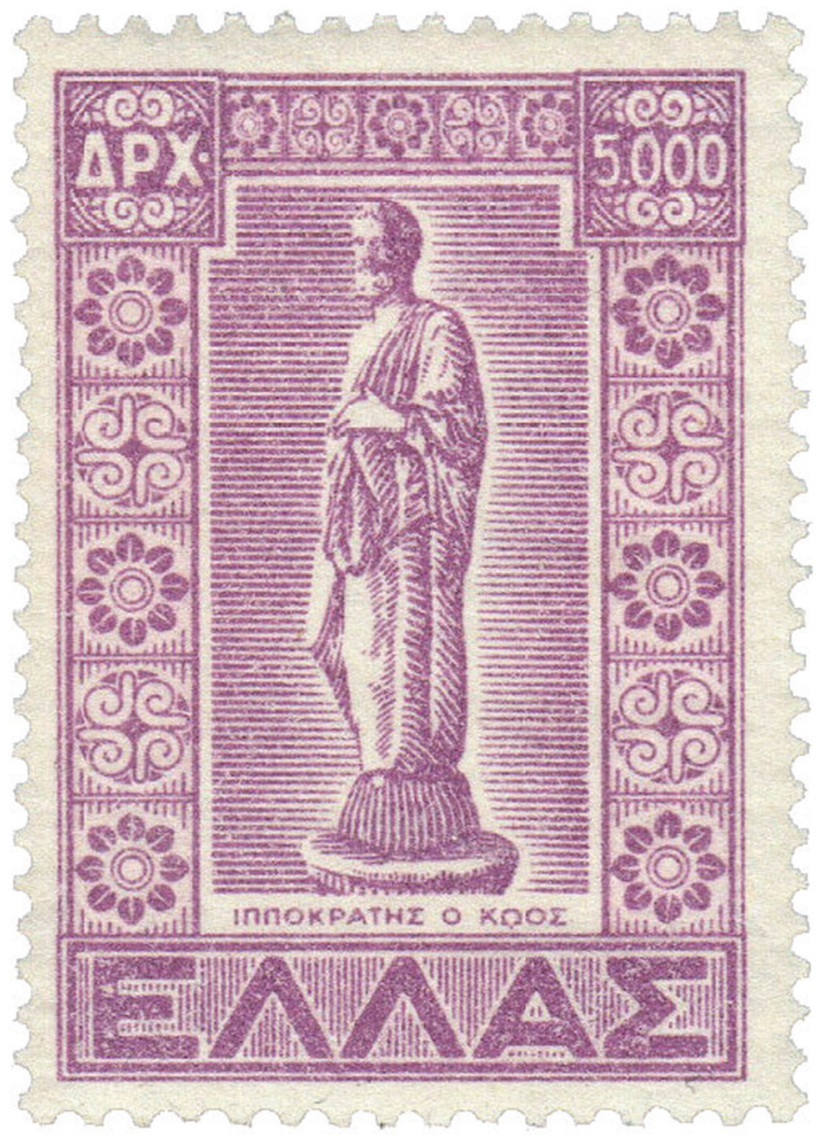

Figure 6: Greece 1950 Mi. 574. 


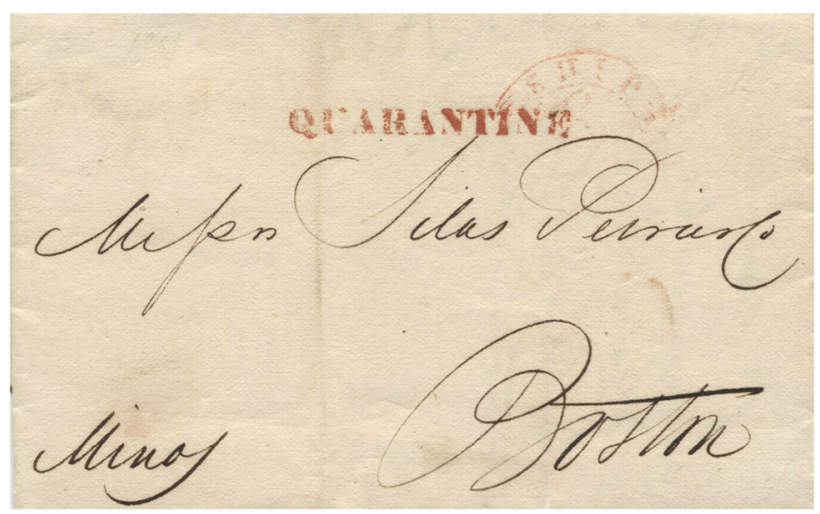

Figure 7: The letter was sent from Havana to Boston in 1825.

the ship and the crew by their port of origin [8], so that in case of a newly emerging plague outbreak in another city, the exposed or suspected crew were kept out. This system was first applied in Venice where it was the center of trade. The city was in great danger from exposure [9] (Figure 7).

First quarantine regulations by England were applied to suspected sailors in 1663 . Two decades later in 1683, new laws were introduced in Marseille which required all individuals who were suspected of plague were to be quarantined and disinfected. In North America, the first applications of quarantine were because of the yellow fever outbreak that hit New York and Boston in 1688 and 1691 respectively [10].

In 1720, another plague epidemic hit Marseille and it spread all around the Mediterranean coast which took the attention of England. There was already a Quarantine Act that passed in 1710 in England but it was renewed in 1721, 1733 and 1743 during a devastating epidemic that hit Messina, Sicily [11]. After that, forming a union was seen to be necessary in order to use as an active surveillance strategy. This network was established by councils from different Levantine lands, so that it connected the Mediterranean ports of western Europe [8] (Figure 8).

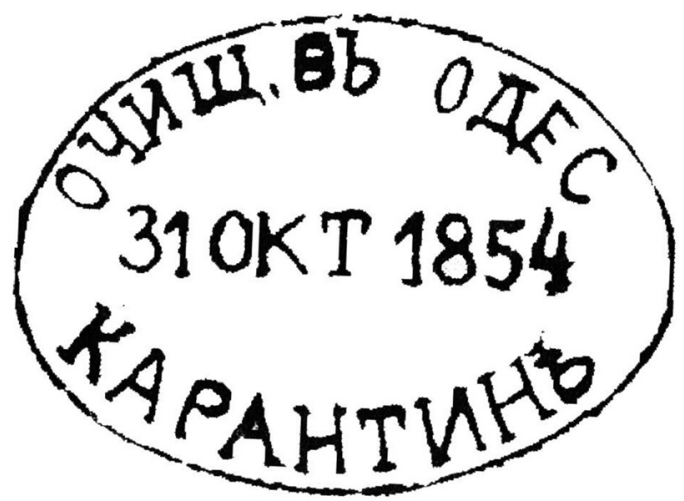

Figure 8: Russian cancellation of quarantine from 1854.
During the rest of eighteenth century, yellow fever outbreaks changed the way France, Spain and Italy implement their precautions. Improvements and discoveries in technology and travel, like steam boats and new railways, contributed globalization in nineteenth century. This factor, has also made various populations more susceptible to newly emerging Cholera epidemic that reached Europe in 1830 and the US in 1832.

\section{Quarantine during cholera pandemic}

During the first wave of Cholera, France put the old sanctions again on practice including the formation of new lazarettos and asking captains for their bills of health. Captain had to officially document that the ship was coming from a region that cholera was not present, otherwise they were barred entry [12]. Some other actions were also taken by authorities like applying quarantine measures to travelers who came from a land that cholera was present or was in contact with a diseased person. Authorities also used force on the ill to be locked down in lazarettos (Figure 9).

In Naples in 1836, health officials and local authorities tried to keep marginalized members of the community away from the city and used quarantine measures to justify disproportionate sanctions. They banned prostitutes and baggers from entering the city centers by considering them as a danger to the healthy urban populations [13]. After the French Revolution in 1789, the increase in quarantine measures was in conflict with the personal freedom that was validated in the citizens' rights. This didn't keep back the authorities to use their force in suppressing the political riots against governments. In Italy, for instance, when

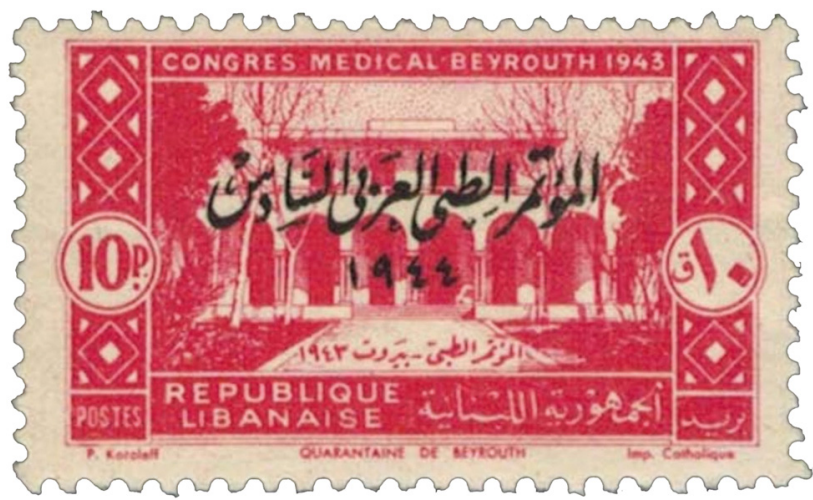

Figure 9: Quarantine building of Beirut from Lebanon in $1943 \mathrm{Mi}$. 277. 
revolutionists were on the rise, enforcement of sanitary measures against cholera was shown as justification for the increased police power [13]. On the other hand, English liberal reformists were discussing both quarantine and compulsory vaccination against smallpox for all citizens (Figure 10).

In mid-nineteenth century, scientists began to discuss the measures like the length of quarantine and the scope for personal goods as well. Quarantine was seen only to protect small islands from yellow fever and cholera just like the example of Sardinia which was the only Italian island that was spared in the 1835-1836 cholera epidemic [13]. With the rise of "anti-quarantinists" who were arguing that the precautions were damaging the commerce and the travelers were hindered because of the fumigation and disinfection processes that took too long. It was obvious that the need for a union was present (Figure 11).

France, in 1834, was the first country to invite others in order to come together and discuss the latest measurements by political and economic means and international standardization of quarantine but no other country responded to this call until the first International Sanitary Conference held in 1851, in Paris [14]. The collaboration

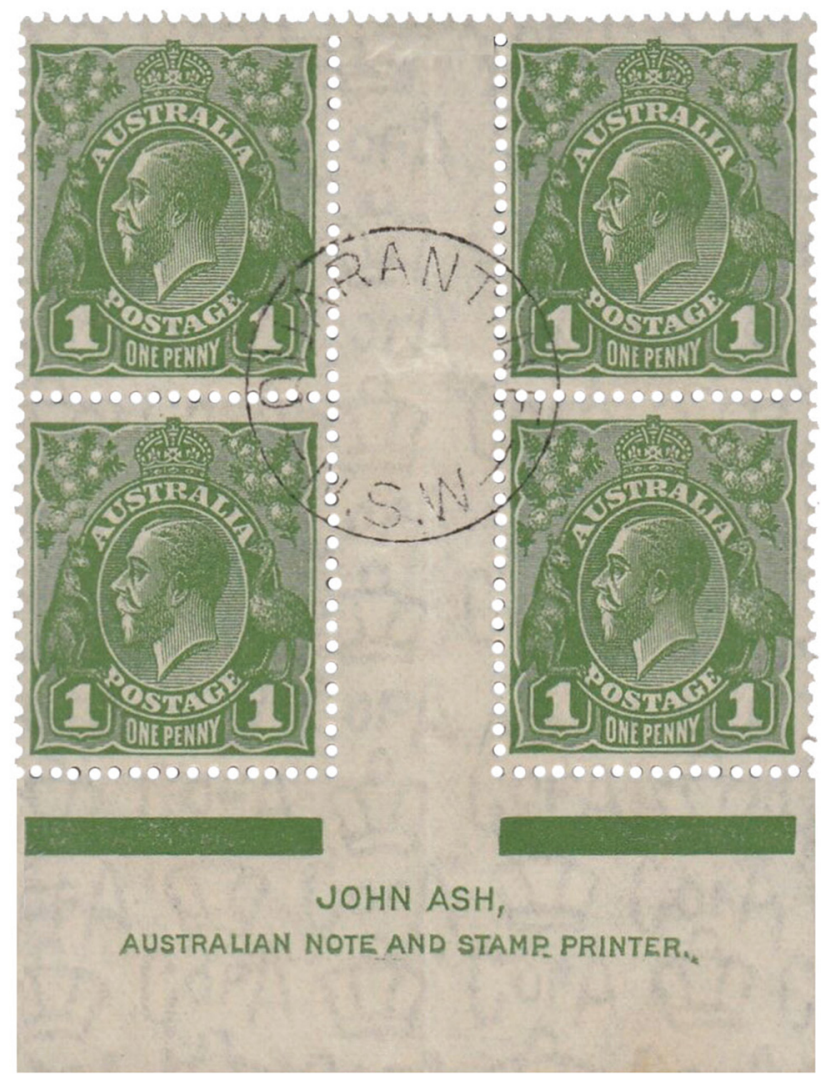

Figure 10: Quarantine cancellation on Australian stamps from 1924.

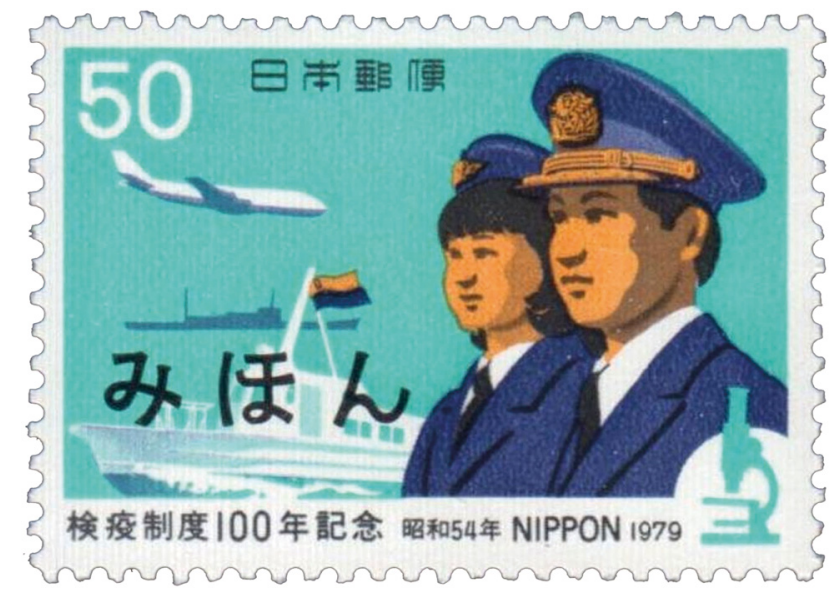

Figure 11: Japanese specimen 1979 Mi. 1393.

was hard to achieve, since the only agenda was not the one health officials had. Economic and bureaucratic officials had their own agendas.

One of the turning points in the history of public health was the identification of pathogens that were causing great fear and panic between the nineteenth and twentieth century. After the identification and classification of each pathogen, international standardized criteria and regulation was approved in 1903 during the 11th Sanitary Conference of which 184 articles were signed [15].

\section{Quarantine during influenza pandemic}

No one was expecting that the nations were once again forced to take serious actions against a pathogen when Influenza struck the world during 1918-1919 era. Multilateral health surveillance systems or Office International d'Hygiène, which is considered as the ancestor of World Health Organization, were unable to help or prevent the spread in a war-torn world, where the scientists were thinking that the pathogen was a bacterium, Haemophilius Influenzae, which was identified by German bacteriologist Richard Pfeiffer in 1892 [16] (Figures 12, 13 and 14).

In the beginning of epidemic, health workers in the military tried to isolate the infected soldiers from the healthy ones but it did not play a major role on the spread. Health authorities in Europe took actions to prevent the outbreak like closing the schools, churches, theaters, any means of social gatherings. In Paris, a sports event with 10,000 young participant was postponed, funerals and church services were cancelled in Italy [17]. Physicians were urging upon respiratory hygiene and social distancing but it was all very 


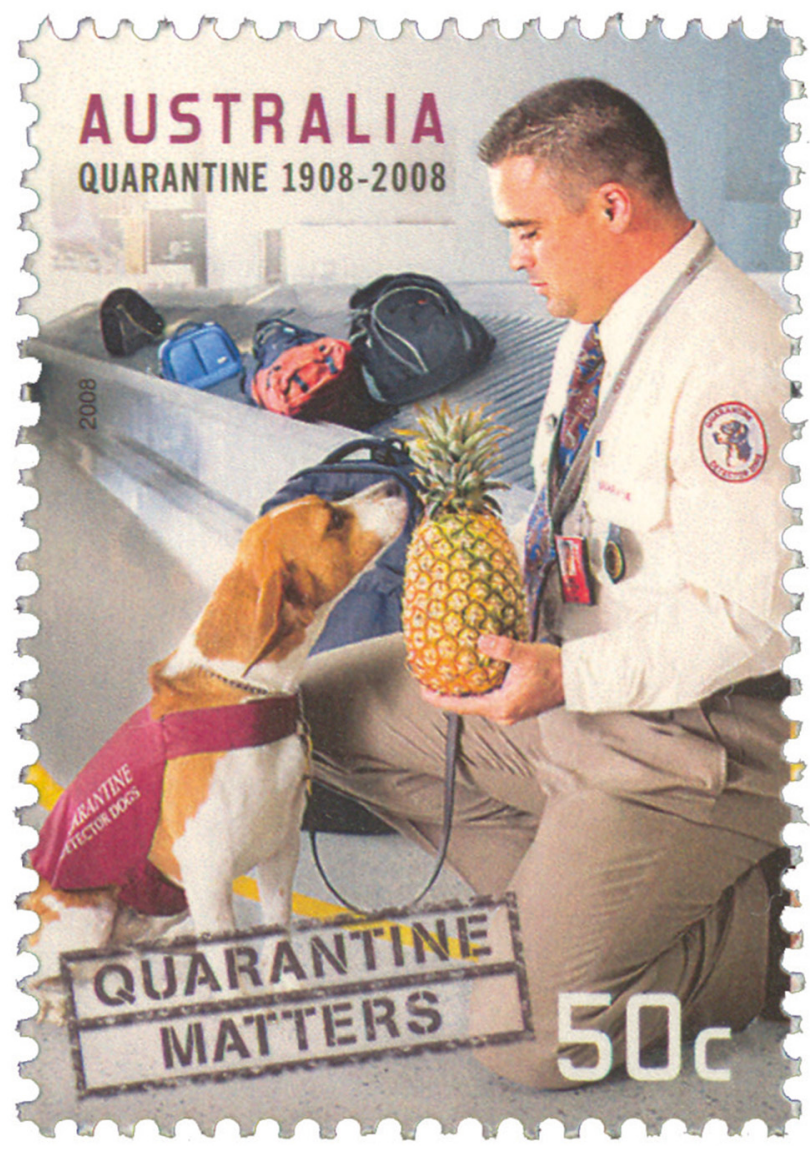

Figure 12: Australia 2008 Mi. 3034.

poorly coordinated because of the ongoing movement of military troops kept spreading the disease. In Italy, which had the most deaths along with Portugal during the Influenza epidemic, closed the schools immediately after the first hemorrhagic pneumonia case. At first, health officials and scholastic authorities were not agreed on the necessity of closure. Health officers were taking actions with the intention of ceasing the spread but it did not work out well. The disproportionately taken measures affected the minorities and marginalized groups atrociously while the authorities were only showing off their effort which in fact resulted ineffectively [16] (Figure 15).

The second Influenza pandemic in the twentieth century was in 1957-1958. Symptoms of the disease were milder. Familiarity with the pathogen since 1933 and also being able to reach seasonal vaccines and anti-microbial agents helped to survive. WHO implemented a global surveillance system for Influenza that gives an early alert when a novel influenza virus began spreading in China in February 1957 and all around the world later that year $[6,7]$. Vaccines were produced in the west but they were not yet available until the schools opened and exacerbate the

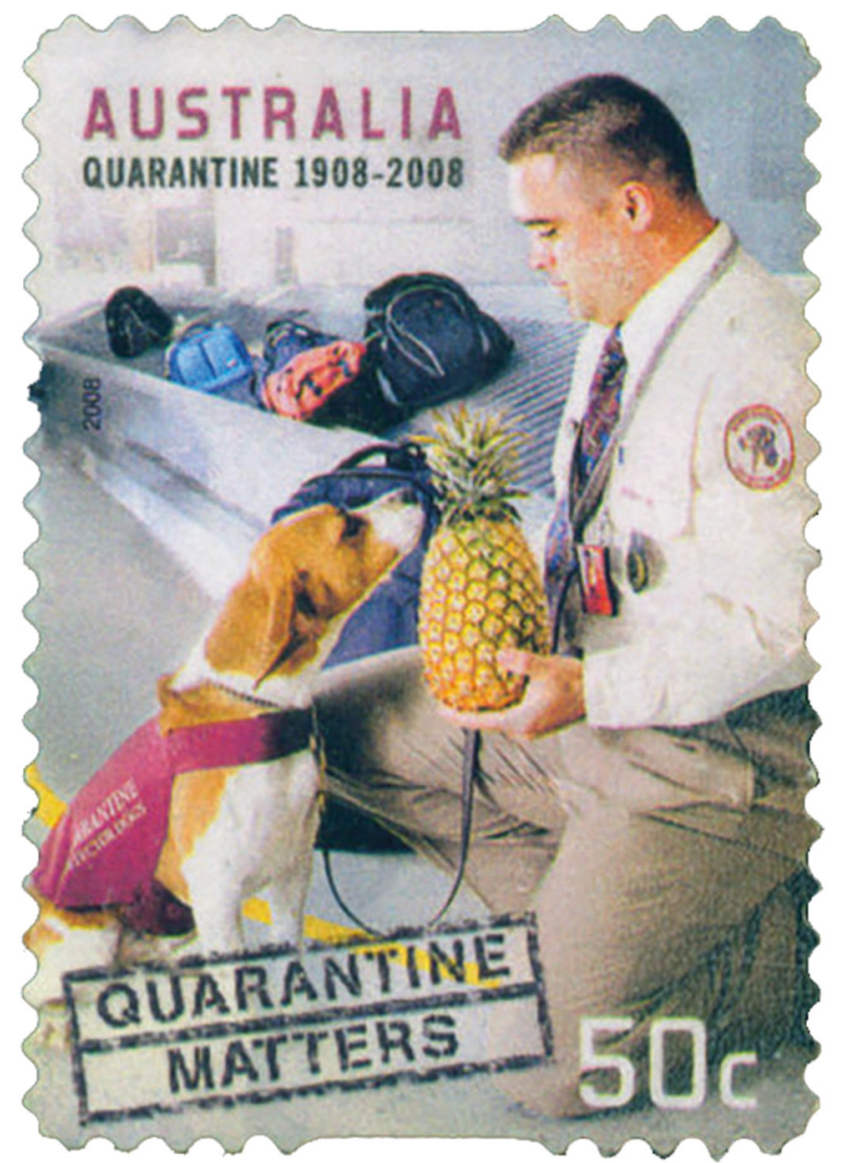

Figure 13: Australia 2008 Mi. 3035 (self-adhesive).

spread. Control measures were differing from one country to another but the closure of asylums, nurseries, and schools was only to postpone the arrival of the disease by a few weeks. Similar actions were taken for the Influenza A pandemic in 1968-1969 winter (Figure 16).

It was the mildest of the twentieth century which was first detected in Hong Kong in early 1968 and was carried to the US in September by US Marines returning homeland from Vietnam. That winter virus spread around the world but its effect was limited and there were no specific containment measures applied.

\section{Quarantine during SARS}

In 2003, SARS was the emerging threat due to its rapid transmission and high mortality rate because of the lack of vaccine and antiviral treatments. Even though it was originated in Guangdong, China; strategies that the health authorities chose were differing in China, Singapore, and Canada. In Canada, people were asked to voluntarily quarantine themselves. On the other hand, in China police 


\section{Richard Pfeiffer 1858 - 1945 Bakteriologe}

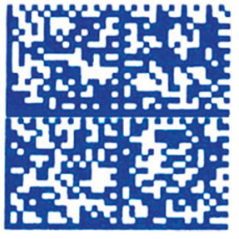

Deutsche Post

FRANKIT 0,45 EUR

09.03 .09
3D01000D11
Figure 14: Slogan from German post for R. Pfeiffer in 2009.

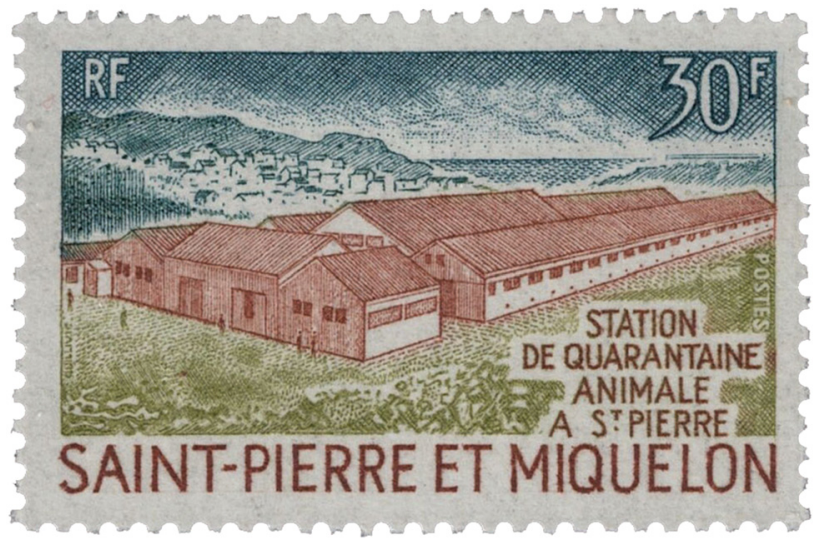

Figure 15: Quarantine station for animals from S. Pierre \& Miquelon from 1970 Mi. 465.

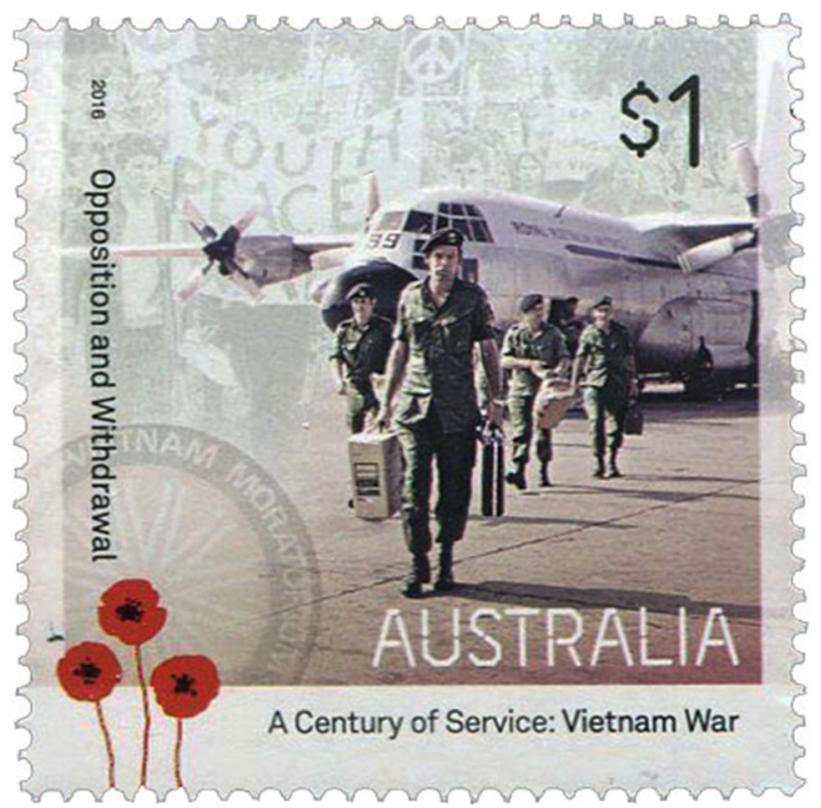

Figure 16: Opposition and withdrawal from Vietnam, Australia 2016 Mi. 4572.

cordoned off the buildings, and organized checkpoints. It was also observed by the global public that the implementation of measures were varying in different social strata [18]. Even some repressive police force and extreme severe punishments were used against the public who violated the quarantine procedures. These actions were officially taken

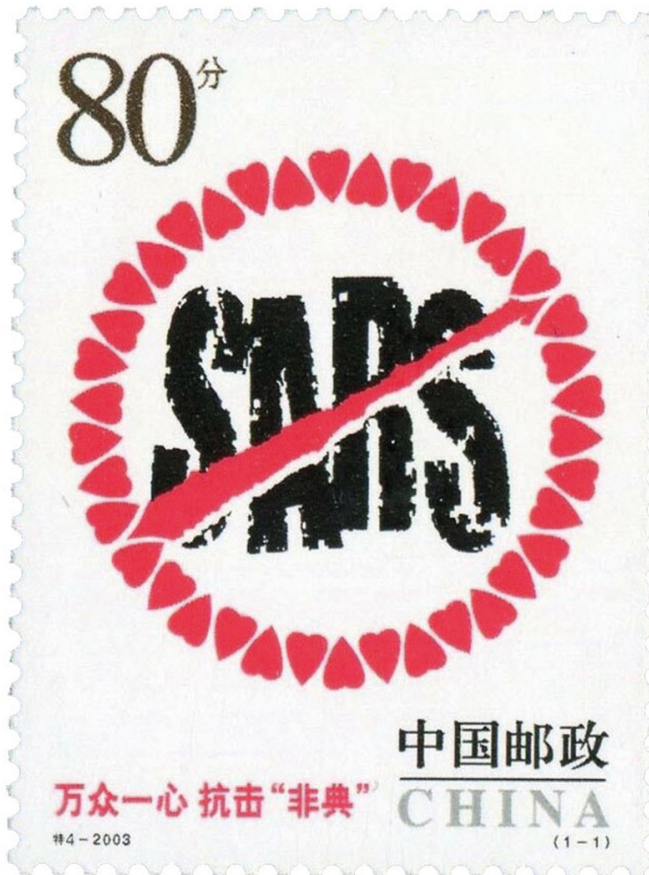

Figure 17: China 2003 Mi. 3447.

by public health officers and local authorities but unfortunately, they contributed to the continuous discrimination and stigmatization against the disadvantaged individuals and the communities, therefore raised complaints against the restrictions and bans (Figure 17).

\section{Conclusion}

After using the term 'quarantine' for centuries, nowadays 'self-quarantine (or self-isolation)' is a term that became popular during the 2019-2020 coronavirus pandemic, which spread to most countries in 2020. Citizens were either encouraged or forced by law to stay home to lower the spread of the disease. Some countries went into lockdowns as a form of quarantine. Although some vaccinations are newly in use, medical professionals in the world stress that success in containing COVID-19 hangs on one big strategy - social distancing or quarantine. This has caused authorities around the world to setup lockdown 
and isolation rules. In most places people cannot meet in large groups, must keep at least two $m$ distance from others - and if you have been in contact with someone testing positive for the coronavirus then you must completely isolate yourself from any contact with others. It is not wrong to say that the world is again in the hands of 'Quarantine' applications until we all develop resistance to the coronavirus through effective vaccines.

Research funding: This research has not received a specific grant from funding organizations in the public, commercial, or non-profit sectors.

Competing interests: The authors declared no potential conflicts of interest with respect to the research, authorship, and/or publication of this article.

\section{References}

1. Grmek MD, Buchet $C$, editors. The beginnings of maritime quarantine [in French]. Man, health and the sea. Paris: Honoré Champion; 1997:39-60 pp.

2. Mafart B, Perret JL. History of the concept of quarantine [in French]. Med Trop (Mars) 1998;58:14-20.

3. McNeill W. Plagues and peoples. New York: Anchor Books; 1998.

4. Office International d'Hygiene Publique. The influenza epidemic that occurred in New Caledonia in 1921 [in French]. Bulletin Mensuel 1922;6:677-85.

5. Ziegler P, Platt C. The black death, 2nd ed. London: Penguin; 1998.
6. Tognotti E. Lessons from the history of quarantine, from plague to influenza A. Emerg Infect Dis 2013;19:254-9.

7. Porter R. Health, civilization and the state: a history of public health from ancient to modern times. London: Routledge; 1999.

8. Cipolla CM. Fighting the plague in seventeenth century-Italy. Madison (WI): University of Wisconsin Press; 1981.

9. Cipolla CM. Public health and the medical profession in the Renaissance. Cambridge: Cambridge University Press; 1976.

10. Toner JM. The distribution and natural history of yellow fever as it has occurred at different times in the United States. Annual report of the supervising surgeon for the fiscal year 1873. Washington (DC): United States Marine Hospital Service; 1873:78-96 pp.

11. Williams G. Angel of death: the story of smallpox. New York: Polgrave McMillan; 2010.

12. Beckmann J (revised and enlarged by William Francis and J. W. Griffith). A history of inventions, discoveries, and origins, 4th ed., vol. 1. London: Henry B. Bohn; 1846:373 p.

13. Tognotti $E$. The Asiatic monster. History of cholera in Italy [in Italian]. Roma-Bari (Italy): Laterza; 2000.

14. Maglen K. Politics of quarantine in the 19th century. JAMA 2003; 290:2873.

15. Howard-Jones N. The scientific background of the international sanitary conferences, 1851-1938. Geneva: World Health Organization; 1975 [cited 2012 Feb 13].

16. Tognotti E. Scientific triumphalism and learning from facts: bacteriology and the "Spanish flu" challenge of 1918. Soc Hist Med 2003;16:97-110.

17. The influenza epidemic [editorial] Lancet.1918;192:595-69.

18. Rothstein MA, Alcalde MG, Elster NR, Majumder MA, Palmer LI, Stone TH, et al. Quarantine and isolation: lessons learned from SARS, a report to the Centers for Disease Control and Prevention. Louisville (KY): Institute for Bioethics Health Policy and Law, University of Louisville School of Medicine; 2003:1-160 pp. 